\title{
多目的ブイを用いたネットワーク型津波警報システムの人的被害 軽減効果に関する研究
}

\author{
Initial Assessment on Capability of Multi-Purpose Buoy System for Tsunami Warning \\ 竹内政彦 ${ }^{1} \cdot$ 越村俊一 $^{2} \cdot$ 目黑公郎 $^{3}$ \\ Masahiko TAKEUCHI, Shunichi KOSHIMURA and Kimiro MEGURO
}

\begin{abstract}
The authors assess the capability of multi-purpose buoy system for tsunami warning, by calculating the number of potential tsunami casualty. The method is developed by integration of tsunami numerical models and GIS analysis with population database and fragility functions. The present method is applied to the potential tsunami events along the Sunda megathrust to assess the effect of tsunami casualty mitigation by implementing international/regional tsunami observation network of multi-purpose buoy system. The results imply that the international tsunami observation network can contribute to reduce the tsunami casualty along the Indian Ocean countries up to $60 \%$ by expecting the lead time to issue the early warning.
\end{abstract}

\section{1.はじめに}

2004年スマトラ島沖地震津波を契機に進められたイン ド洋津波警報システム構想（たとえば IOC，2006）は, 太平洋の津波警報技術のインド洋への移転を前提とした あのである.しかし，高度な津波警報技術の運用はイン ド洋沿岸諸国にとって財政的負担が大きいことに加え, 運用にあたる人材の育成, 技術課題の解決, 維持管理の 持続可能性に大きな不安が残る.これらの課題を克服す るため, 安価で維持管理しやすく, 特に沿岸漁業や観光 業の日常的な海洋観測ニーズを満たすブイ（多目的ブイ） をインド洋沿岸地域で運用し，そのブイで津波観測も行 うことで予報体制を構築するという新しい津波防災対策 が目黒・高島(2006)によって提案された. 本研究は, 多 目的ブイネットワークによる津波警報システムの有効性 を，観測情報の活用による人的被害軽減効果に着目して 検証を行うことを目的とする.

まずインド洋で起こりうる津波を網羅的に考慮するた め, スンダ海溝沿いに160通りの地震津波シナリオを想 定し, 各地域の津波浸水エリア内の人的被害数を推計す る。次に, 160 通りの津波シナリオに対し, 津波が発生 した際に最む早く津波を検知し観测情報を発信できる地 域を推定し, 多目的ブイネットワークの人的被害軽減効 果を各地域の避難の実施による人的被害の軽減率と軽減 数との関連で評価する. 最後に, 多目的ブイネットワー クの有効性を検討するため, 各津波シナリオにおいて, インド洋全体でブイをネットワーク化して観測情報を共 有した場合と各国内の観測網だけで情報共有した場合の 人的被害軽減率の差を比較する.

\begin{tabular}{lll}
\hline 1 & 工修 & 財務省主計局 \\
2 正 会 員 & 博(工) & 東北大学准教授 大学院工学研究科 \\
3 正 会 員 & 工博 & 東京大学教授
\end{tabular}

\section{2. 津波による人的被害の推計}

\section{(1) 想定津波と数值解析}

図-1に示すように, $\left(20^{\circ} \mathrm{S}, 65^{\circ} \mathrm{E}\right)$ から $\left(25^{\circ} \mathrm{N}, 130^{\circ} \mathrm{E}\right)$ ま でを計算領域として津波の数值解析を行う。計算には, 地球座標系の線形長波理論に基づく差分モデルを採用す る（たとえば Nagano ら，1991）。空間格子間隔は1分 (約 $1,800 \mathrm{~m}$ ), 時間格子間隔は3秒, 時間積分は 14,400 step （12時間）とした。海底地形デー夕は, GEBCO (British Oceanographic Data Centre, 1997)の1分グリッドデータを 利用した。 インド洋で発生し得る巨大地震の発生地域に ついては, USGS による1971年以降の地震震央分布とテ クトニクスを考慮し, スンダ海溝沿いに限定することと した. 図-1中の・は，本研究で想定した地震断層の基準 点の位置である、スンダ海溝に沿って40点を設定し，既 往のスンダ海溝沿いの巨大地震を考慮してモーメントマ グニチュード $M_{\mathrm{w}}$ を $8.0,8.3,8.7,9$ の4通りで計160ケー スのプレート境界型低角逆断層地震を想定した。断層面 の走向はプレート境界と整合するようにし, 断層面基準 点 (上端) の深さは $10 \mathrm{~km}$ とした. また, 断層長さ・幅 $L, W は$, Wells・Coppersmith(1994)による断層モデルの 幾何学的経験則に整合するように決定し, 断層滑り量 $D$ は佐藤ら（1989）による $M_{w}$ と $M_{o}$ の関係式加ら地震モー メント $M_{0}$ を求め, $M_{0}=\mu D L W$ の関係式から算定した (地盤の剛性率 $\mu=3.0 \times 10^{10} \mathrm{~N} / \mathrm{m}$ ).

\section{(2) 人的被害推計モデル}

津波による人的被害の推計モデルは, 越村ら（2005） が提案した Potential Tsunami Exposure（津波曝露人口） の推計モデルを基礎として，ブイによる津波警報の発令 から各国沿岸部への津波到達までのリードタイムと避難 率，および津波浸水深に対する死亡率を考慮する。津波 浸水域内（計算格子毎）の推定死亡者数 PED（Potential 


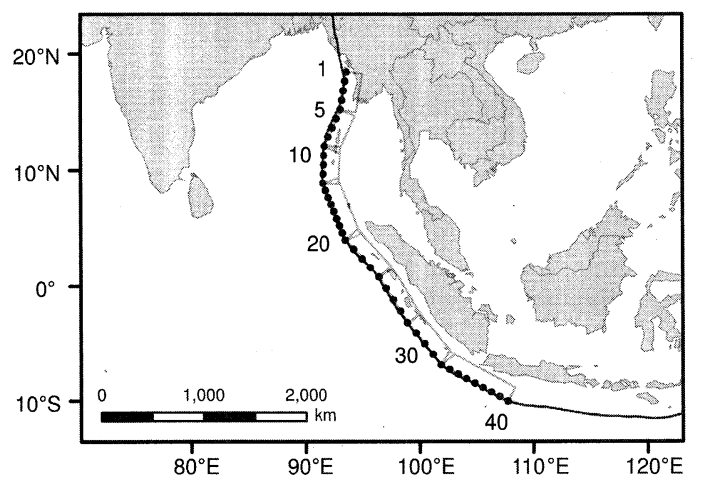

図-1＼cjkstart計算領域と地震シナリオの概要（図中の数字は断層の番号）

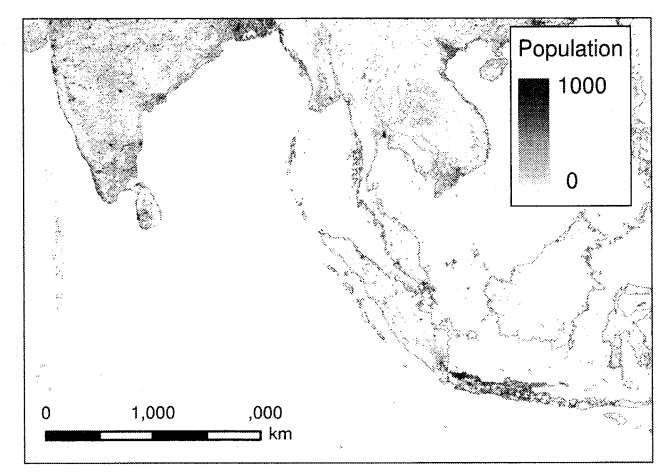

図-2人口統計データ(LandScan)

Exposed-Death）を次式のように定義する.

$$
P E D(\eta, L T, P o p)=\alpha(\eta)\{1-\beta(L T)\} P o p
$$

ここで $\eta$ は浸水深， $L T$ は津波観測・警報によるリード 夕イム (後述), Pop は浸水域内人口 (計算格子毎), $\alpha$ $(\eta)$ は浸水深 $\eta$ に応じた死亡率， $\beta(L T)$ はリードタイ ムに応じた避難率である。

陸上の津波浸水深および曝露人口を算定すべき陸地の 格子は, 標高 $30 \mathrm{~m}$, 海岸線から $5 \mathrm{~km}$ を制約条件として設 定する. 浸水深 $\eta$ は, 対象とする陸上格子から最短の海 域の格子を GIS を用いて探索し，そこの計算津波高を 代表值として算出した。また， $\eta$ を算出した陸上格子と 人口統計デー夕 (Ork Ridge National Laboratory, 2006) を GIS 分析により関連づけ, 浸水した陸上格子毎に浸 水域内人口 $P o p$ を算出した.

津波による人的被害は, 大家ら（2006），木村ら （2006）が2004年スマトラ島沖地震津波の被害事例を用 いて浸水深に対する死亡率という形でそれぞれ提案して いる。ここでは, Koshimura ら（2008）が Banda Aceh の 津波浸水計算人人的被害デー夕を元にして構築した Fragility 関数を利用する。津波による人的被害の

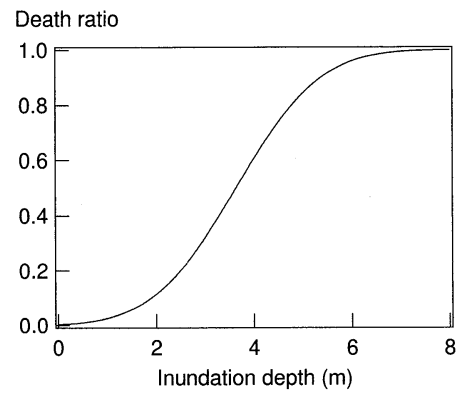

図-3 津波浸水深に対応した人的被害関数

Fragilityを図-3および次式に示す.

$$
\alpha(\eta)=\Phi\left[\frac{\eta-\mu}{\sigma}\right]
$$

$\phi$ は標準正規分布の累積確率分布関数であり， $\mu, \sigma$ は それぞれ $\eta$ の平均值および標準偏差 $(\mu=3.634, \sigma=1.356)$ である。

\section{(3) 津波観測によるリードタイムと避難率}

リードタイム $L T$ とは，津波警報発令から沿岸部への 津波到達までの時間（分）として次式で定義し，ブイの 設置地点 (後述) と沿岸部に扔いてそれぞれ数值解析結 果から求めておく.

$$
L T=T_{a r}-T_{0}
$$

ここで $T_{a r}$ は沿岸の津波到達時間（水位変動土 $20 \mathrm{~cm}$ 以上 が記録された時間）として沿岸域の計算格子毎, 津波イ ベント毎に計算しておく。 $T_{0}$ は津波警報発令時間であ り, 設置したブイが最す早く津波を検知した時間 $T_{i}$ (水 位変動土 $20 \mathrm{~cm}$ が観測される時間）に15分の猶予を加え, 式(4)で定義する。15分の猶予を設定したのは，2004年 スマトラ島沖地震津波の周期約 1 時間の $1 / 4$ 周期に相当す る時間を津波検知の時間として見積むったためである. 過去の事例としては，2007年9月11日11:10（UTC）に発 生したスマトラ島沖地震時に発震後14分で太平洋津波警 報センター（PTWC）加ら津波警戒速報第1報が伝えら れている.

$$
T_{0}=T_{i}+15.0
$$

リードタイムに対する避難率 $\beta$ は, 津波災害について は既往の研究がない，ここでは，片田ら（2000）による 豪雨災害時の住民の情報取得に関する研究と, 岡本・目 黒（2007）の津波避難行動シミュレーションの結果を参 考にして，便宜的に図-4に示すように与えた。

\section{(4) 人的被害推計結果}

上述した手法に従い，160通りの津波発生シナリオに 基づく津波数值解析を実施し, 人的被害 PED の推計を 行った. 図-5に例示するのは, スンダ海溝に沿って $M_{w}=$ 


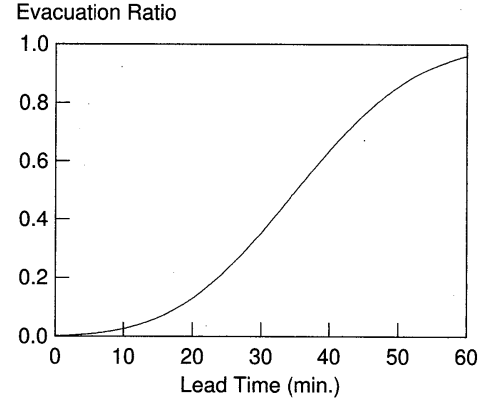

図-4 リードタイム $L T$ と避難率 $\beta$ の関係

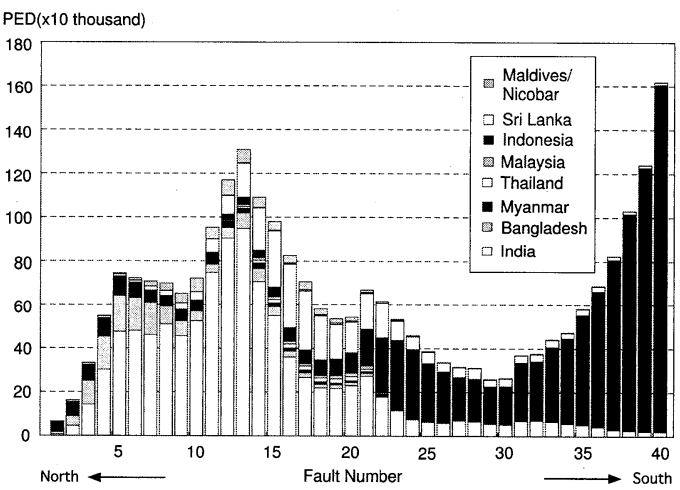

図-5 インド洋沿岸諸国の $P E D$ 試算結果(M8.7の地震の例)

8.7の地震の発生を想定した PED の国毎の試算結果であ る. 図の横軸は断層番号（図-1参照）で，各番号で示し た位置の断層帯で地震津波が発生した場合の PEDを, 上からモルディブ/ニコバル，スリランカ，インドネシ ア，マレーシア，夕イ，ミャンマー，バングラディシュ， インドの順に示してある。ただし，ここで示した結果は， 避難行動を考慮していない $(\beta=0)$. 国毎の人的被害の 様相は津波発生地により異なり, 特に断層番号 20 番を境 にして顕著に現れる。すすなお，スマトラ島以北で巨大 地震が発生した場合には，インドに扔ける人的被害が大 勢を占め，スマトラ島以南の場合にはインドネシアでの 人的被害が圧倒的に増加することが分かる.

次に，地震の発生確率を考慮して，PED の期待值を 算出する。これにより，潜在的な津波被災者が多いと考 えられる地域を探索することが可能である。.まず，イベ ント $i$ の沿岸部津波浸水域内0推定死亡者数 $P E D_{i}$ を求 め，イベント毎の津波発生確率 $K_{i}$ を乗じて総和をとる ことにより, 人的被害の $P E D$ の期待値を式(5)により算 出する。

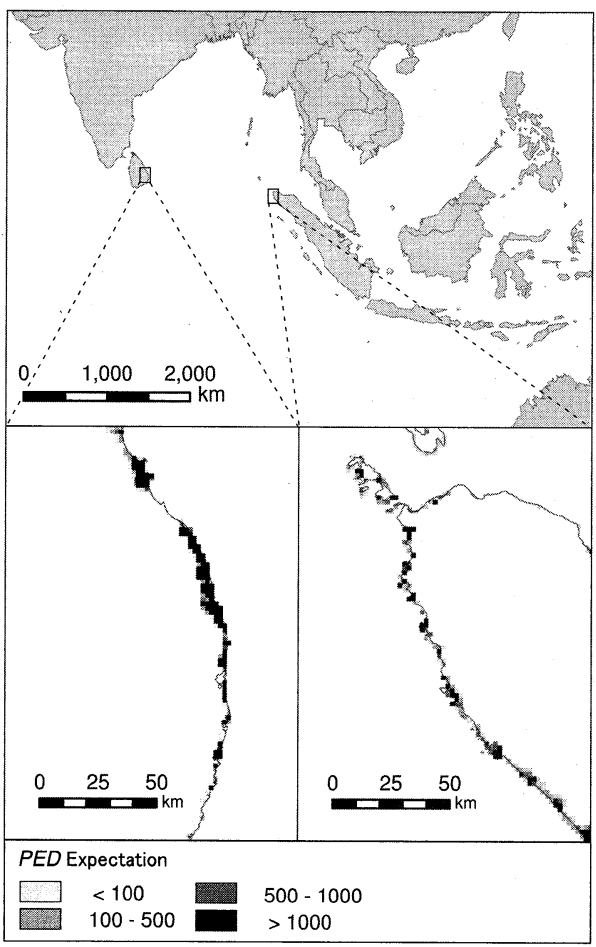

図-6 インド洋の津波危険度 (PED の期待值)

$$
\sum_{i=1}^{160} K_{i} \times P E D_{i}
$$

ただし，スンダ海溝沿いの巨大地震発生確率について は未解明な部分む多く, Sieh(2007)がスンダ海溝の北部 之南部に分けて歴史津波之現在の地盤の変動量から, 今 後の発生危険度について定性的に考察しているあのの, 現段階では定量的に示されたものがない。また，スマト ラ島付近以外の地震津波についての言及がないなどの懸 念があるが, 本研究では $K_{i}$ をグーテンベルク・リヒター の式(6)を援用して求めた.

$$
\log n=a-b M
$$

ここで $n$ は地震のマグニチュード $M$ に対して統計を とった地震の発生回数であり, $a$ および $b$ は地域毎に同 定される定数である。ここでは $b=1$ と仮定した，発生し 得る地震のマグニチュードに応じて $K_{i}(i=1,160)$ を算出 した. たとえば， $M=8.0$ の場合には，上式から求まる地 震発生回数を $n_{M}\left(M_{w}=8.0,8.3,8.7,9.0\right)$ として, 式(7)で 算出した $\left(K_{i}\right.$ の総和は1になる）.

$$
K i=\frac{n_{8} / 40}{n_{8}+n_{8.3}+n_{8.7}+n_{9}}
$$

図-6に，算出した $P E D$ の空間分布の例（スリランカ 


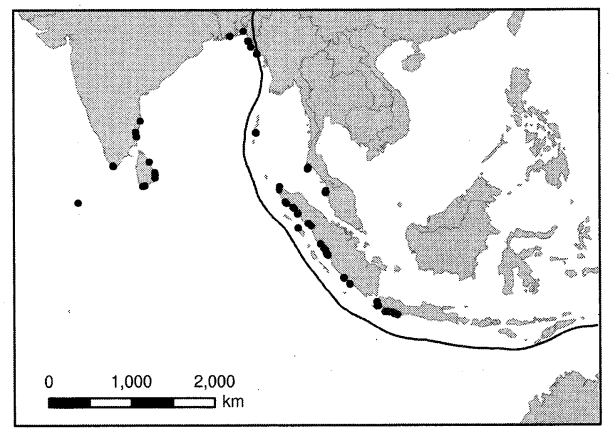

図-7 多目的ブイの設置位置

東岸とスマトラ島北部）を示す。スマトラ島北部では, 西岸に沿って PED が高く, 人口分布と津波高に応じて 津波危険個所を選定することができた。

\section{3. 津波警報システムによる人的被害軽減効果}

上述の評価手法を踏まえて, 多目的ブイネットワーク による予報体制の有無による被害軽減効果を議論する. ここでいう多目的ブイとは, 沿岸部の事業主体（自治体, 観光業者, 漁業関係者, リゾートホテル等）が運用する ことを想定しており，たとえば加藤ら（2005）により提 案されている GPS ブイを沿岸部に設置することによる 津波検知を想定している. ブイの仮想設置位置は, 人口 1 万人以上の都市の沿岸を制約条件として，160ケースの 想定津波毎に最も早く津波が到達する地点を設置可能地 点とした．図-7に，想定したブイ設置位置を示す。これ らのブイネットワークによる津波の早期検知を考慮して, リードタイムに対応した避難率を考慮して人的被害数を 推計する．また，ブイのネットワーク化による効果を見 るために，ブイからの津波検知情報をインド洋沿岸諸国 が各自で利用して予報を行う場合とインド洋全体で共有 する場合に分けて検討を行った。

$$
P M R=\sum_{i=1}^{160} K_{i} \frac{\alpha(\eta) \text { Pop }_{i}-\text { PED }}{\alpha(\eta) \text { Pop }_{i}}
$$

人的被害軽減効果 (PMR:Potential-damage Mitigation Ratio）を式(8)に示す.すなわち，イベント $i$ 毎にリード タイムの有無による $P E D$ の差を分子にとり, リード夕 イムを考慮しない場合の $P E D$ で除した值として定義す る.リードタイム $L T$ の算出には, 図-7に示した仮想ブ イ設置位置と沿岸部で出力した計算津波波形を用いた。

図-8に, 夕イ南部・スマトラ島およびインド南部・スリ ランカに打ける $P M R$ の空間分布を例示する．PMR の算 定には，インド洋全体でのブイの活用（図-7の配置）を 前提とした．図の見やすさのため, $P M R>0.3$ の地域のみ を黒いドットで示してある. スンダ海溝沿いの巨大地震

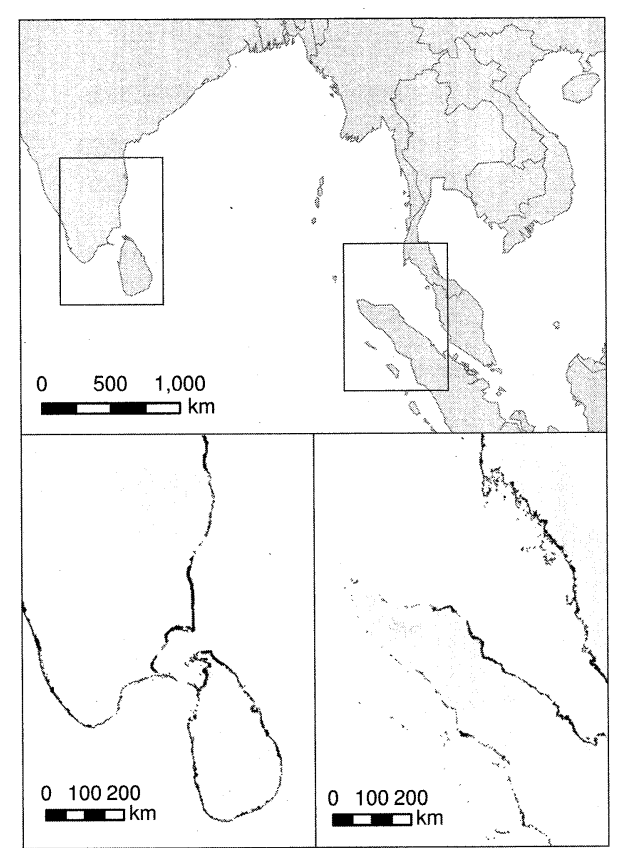

図-8 インド洋沿岸の人的被害軽減率の期待值(PMR)

の発生を考えた場合, 波源から遠方にある地域ではブイ による津波検知の効果が高いと判断できる. しかし, 波 源に近いスマトラ島西岸におけるブイの効果は他国より 低く（インドネシア全体で, $P M R$ は 0.2 程度), スマト ラ島では，ブイ観測による人的被害の軽減には限界があ ることが分かる.これは，スマトラ島への津波の到達時 間が他のどの地域よりあ早く, インド洋全体で観測情報 を共有したとしても，リードタイムを大幅に稼ぐことが 難しいためである。このような地域では, 津波観測施設・ 予警報システムの整備に加え, 迅速な避難を促すための 対策も必要となる。

最後に, インド洋全体で国際的な津波観測ネットワー クを構築した場合之, 各国が独自の観測網で津波検知を 行った場合の人的被害軽減効果を比較した結果を図-9に 示す.インド洋全体で津波観測情報を共有することによ り, 多くの国で人的被害軽減効果が見込めることが分か る(最大 9 倍程度の被害軽減効果)。ただし，この結果に は津波波源近傍のスマトラ島沖での観測施設の整備が大 きく寄与していることに注意が必要である。自国沿岸部 だけでなく、インド洋全体という大局的視野に立った観 測施設の整備と情報共有が重要である、インド洋沿岸諸 国が津波対策を考える場合には，自国周辺の津波観測体 制のみに目を向けるのではなく, 他国の観測施設屯融通 しあって活用することが人的被害の軽減に大きく寄与で きることが明らかになった。たとえば上記の結果を活用 して, 沿岸各地のブイ設置・維持費用負担率を決定する 


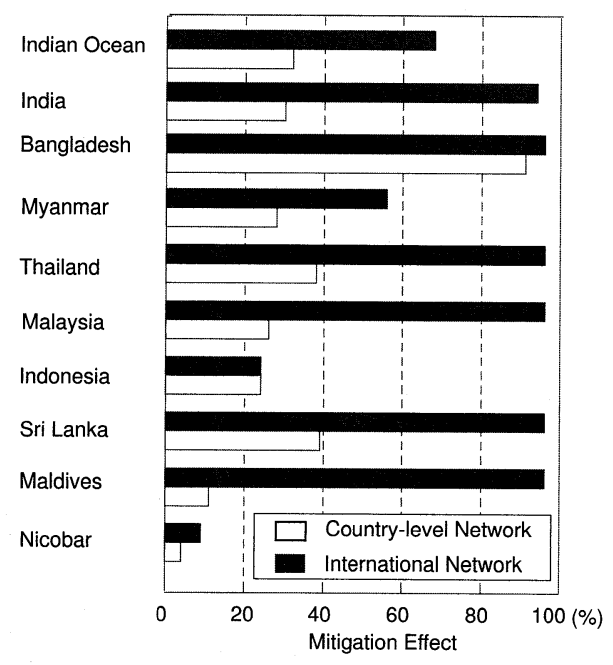

図-9 ブイのネットワーク化によるPMRの国別比較

などの仕組みが望まれる.

\section{4. おわりに}

本研究で得られた結果を以下に列挙する。

各地域の津波危険度を，津波が発生した際に被害者の 絶対数が多い地域 ( $P E D$ の期待值高) として定量的に示 すことができた。この結果は，津波防災対策推進地域の 優先順位付けに利用できると考えられる.

インド洋沿岸において, 津波による人的被害の軽減に 効果的な多目的ブイの設置位置を推定した。主にミャン マー, ニコバル, インドネシアが津波観測情報発信国と なればインド洋全体での人的被害の軽減が可能であるこ とが分かった。

各地の人的被害軽減率 $P M R$ を推計した結果，広範囲 に多目的ブイのネットワークを構築すれば人的被害の大 幅削減が可能であることが分かった．特にインド・スリ ランカ・バングラディシュ・タイなどでは最大 $96 \%$ の軽 減が可能である。 また, 多目的ブイネットワークによる 人的被害軽減率の期待值は, 沿岸各地のブイ設置・維持 費用負担率を決める際にあ活用できる.

国毎の多目的ブイのネットワーク化の効果を，人的被 害軽減率を尺度にして，自国内のみでネットワーク化す る場合とインド洋全体で共有する場合に分けて評価した。 その結果, インド洋全体で観測ネットワークを整備した 場合には, 自国のみの場合に比べて最大 9 倍程度の人的 被害軽減が見込めることが分かった．多目的ブイによる 観測ネットワークが津波警報システムとして十分な効果
を持っことが分かった。

謝辞：本研究の一部は, 科学研究費補助金基盤研究 (A) （代表：目黒公郎，課題番号：18254002）抢よび平成20 年度産業技術研究助成事業（代表：越村俊一，プロジェ クト ID：08E52010a）の補助を受けて実施された。ここ に記して謝意を表する。

\section{参考 文 献}

大家隆行・越村俊一・柳澤英明・今村文彦（2006）：2004年1 ンド洋大津波によるバンダ・アチェ市街地の津波氾濫解析 之被害評価, 海岸工学論文集, 第53巻, pp.221-225.

岡本 睦・目黒 公郎 (2007)：避難行動シミュレーションに基 づく避難困難度マッピングシステムの構築，第62回土木学 会年次学術講演会講演概要集, CD-ROM.

加藤照之・寺田幸博・越村俊一・永井紀彦（2005）：GPS 津波 計による津波観測, 月刊地球, Vol.37, No.3, pp.179-183.

片田敏孝・淺田純作・桑沢敬行（2000）：GIS を用いた災害情 報伝達のシミュレーション分析, 土木情報システム論文集, Vol.9, pp.49-58.

木村健太郎・石見和久 ・ 佐藤誠一・福田忠弘・ 三上勉・菊池茂 （2006）：スマトラ沖地震津波被害実態調査に基づく波源モ デルの検証と建物被害関数の提案ースリランカ国 Matara 市 の被害を対象として-, 海岸工学論文集, 第53巻, pp.301305 .

越村俊一 ・高島正典・鈴木進吾・林春男 - 今村文彦・河田惠昭 （2005）：インド洋における巨大地震津波災害ポテンシャル の評価, 海岸工学論文集, 第52巻, pp.1416-1420。

佐藤良輔（編）（1989）：日本の地震断層パラメター・ハンドブッ ク, 鹿島出版会, 390p.

目黒公郎・高島正典（2006）：沿岸産業主導による津波災害軽 減に向けてー多目的観測ブイを用いた津波警報システムの 提案-，土木学会誌，第91巻，第7号，pp.42-43.

British Oceanographic Data Centre (1997) : The Centenary Edition of the GEBCO Digital Atlas (CD-ROM)

Intergovernmental Oceanographic Commission(2006) : Indian Ocean Tsunami Warning andMitigation System (IOTWS), http://ioc3.unesco.org/indotsunami/

Koshimura, S., T. Oie, H. Yanagisawa and F. Imamura (2008) : Developing fragility functions for tsunami damage estimation using numerical model and post-tsunami data from Banda Aceh, Indonesia, Coastal Engineering Journal, JSCE, submitted.

Mansinha, L. and D. E. Smylie (1971) : The Displacement Fields of Inclined Faults, Bull. Seism. Soc. Amer., 61(5), pp.14331440.

Nagano, O., F. Imamura and N. Shuto (1991) : A Numerical Model for Far-Field Tsunamis and Its Application to Predict Damages Done to Aquaculture,Natural Hazards, 4, pp.235255.

Ork Ridge National Laboratory (2006) : LandScanTM Global Population Database http://www.ornl.gov/sci/landscan/

Sieh, K. (2007): The Sunda megathrust -Past, present and future, Journal of Earthquake and Tsunami, Vol. 1, No.1, pp.1-19.

Wells, D. L. and K. J. Coppersmith (1994) : New Empirical Relationships among Magnitude, Rupture Length, Rupture Width, Rupture Area, and Surface Displacement, Bulletin of the Seismological Society of America, 84 (4), pp.974-1002. 